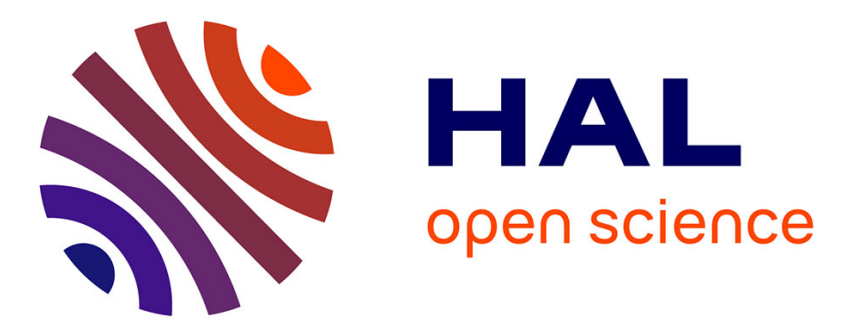

\title{
AGARICOMYCETES MEDICINAL MUSHROOMS WITH POTENTIAL NEUROPROTECTIVE ACTIVITY GROWING IN ARMENIA
}

Susanna Badalyan, Sylvie Rapior

\section{- To cite this version:}

Susanna Badalyan, Sylvie Rapior. AGARICOMYCETES MEDICINAL MUSHROOMS WITH POTENTIAL NEUROPROTECTIVE ACTIVITY GROWING IN ARMENIA. Proceedings of the Yerevan State University - Chemical and Biological Sciences, 2020, 54 (3), 10.46991/PYSU:B/2020.54.3.000 . hal-03090953v1

\section{HAL Id: hal-03090953 https://hal.umontpellier.fr/hal-03090953v1}

Submitted on 30 Dec 2020 (v1), last revised 4 Feb 2021 (v2)

HAL is a multi-disciplinary open access archive for the deposit and dissemination of scientific research documents, whether they are published or not. The documents may come from teaching and research institutions in France or abroad, or from public or private research centers.
L'archive ouverte pluridisciplinaire HAL, est destinée au dépôt et à la diffusion de documents scientifiques de niveau recherche, publiés ou non, émanant des établissements d'enseignement et de recherche français ou étrangers, des laboratoires publics ou privés. 
PROCEEDINGS OF THE YEREVAN STATE UNIVERSITY

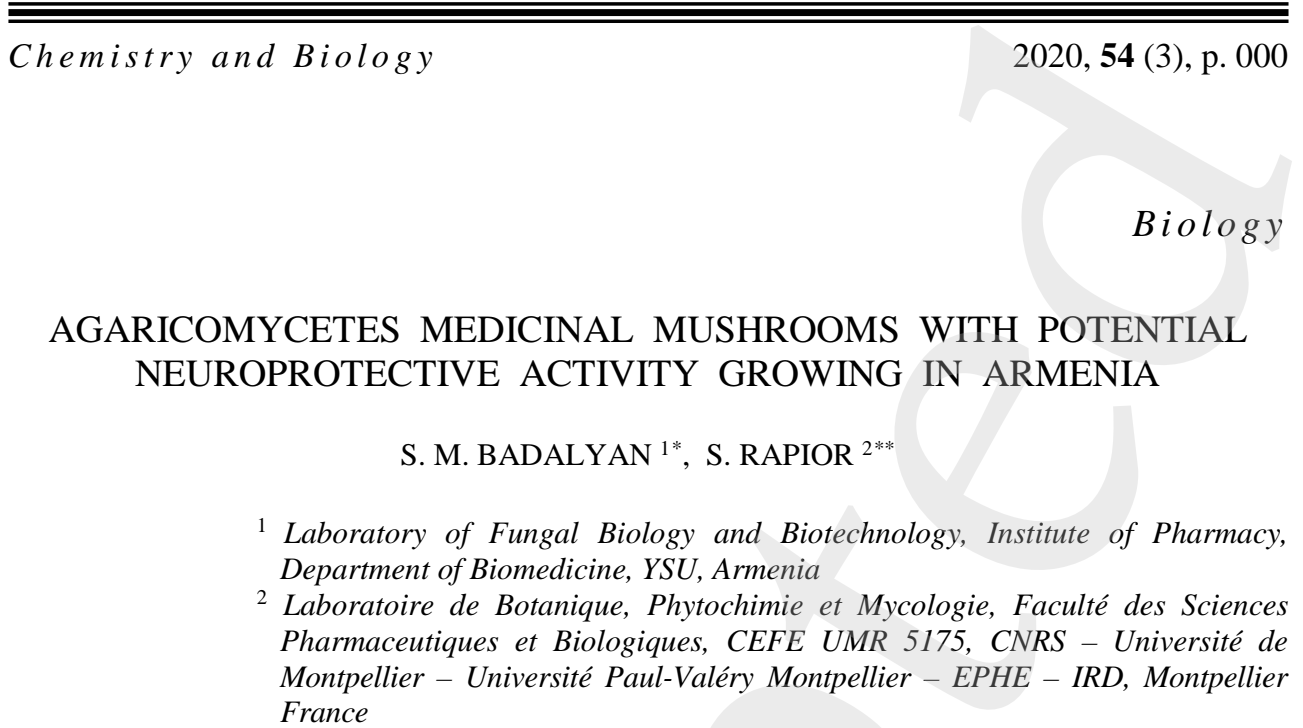

The Agaricomycetes mushrooms (phylum Basidiomycota) are recognised sources of valuable food and medicines. They are producers of bioactive compounds (phenolics, polysaccharides, proteins, steroids, terpenoids, etc.) possessing around 130 therapeutic effects (antimicrobial, anti-inflammatory, antioxidant, immunomodulatory, etc.). Mushrooms are also reported as potential neurotrophic and neuroprotective agents. Seventeen edible and inedible agaricomycetous species from different taxonomic and ecological groups have been reported in Armenia to possess neuroprotective activity. Evaluation resource value and biotechnological potential of Armenian agaricomycetous mushrooms will assist further development of novel myco-pharmaceuticals to prevent andmitigatedifferent disorders, including neurodegenerative.

https://doi.org/10.46991/PYSU:B/2020.54.3.000

Keywords: Agaricomycetes, antioxidant, anti-inflammatory, mushrooms, neurodegenerative, neuroprotective.

Introduction. Agaricomycetes mushrooms (phylum Basidiomycota) are rich sources of bioactive compounds (alkaloids, phenolics, polyketides, polysaccharides, proteins, ribosomal and non-ribosomal peptides, steroids, terpenoids, etc.) possessing more than 130 therapeutic effects (analgesic, antibacterial, antifungal, anti-inflammatory, antioxidant, cytotoxic, hepatoprotective, hypocholesterolemic, hypoglycemic, hypotensive, immunomodulatory, mitogenic/regenerative, etc.) [1-7]. Theyhave also been reported as neuroprotective and anti-depressive agents [8-14].New screening strategies based on innovative genetic approaches have identified novel mushroom metabolites-derived products widely applicable in biomedicine [15]. The evaluation of resource value and establishment of specialized culture collections of Agaricomycetes fungi will have an incredible impact on biomedical research that will assist to develop novel myco-pharmaceuticals [6, 16, 17].

* E-mail: s.badalyan@ysu.am

** E-mail: sylvie.rapior@umontpellier.fr

\section{Changes may still occur before final publication.}


Neurodegenerative disorders (NDD) including age-related Alzheimer (AD) and Parkinson diseases (PD), dementia, autism, depression and epilepsy are affecting millions of people worldwide. Stress-less lifestyle and healthy diet prevent development of such pathological conditions [18]. Oxidative stress and neuro-inflammation, protein aggregation and mitochondrial dysfunction are considered to play an important role in the etiopathogenesis of NDD $[8,18,19]$. Available therapies are associated with mild to severe side-effects, therefore, the search for novel approaches and natural resources of bioactive compounds that regulate pathways leading to neuronal death and dysfunction are warranted $[6,8$, $20,24,33]$.

Recent studies focus on the pharmacology and feasibility of bioactive compounds of plant and fungal origin as a potential strategy to target a variety of human metabolic and brain disorders [37]. The mechanism and possible synergy of action of these compounds has not been studied yet, however mushrooms-derived products with potential neuroprotective and psychotropic activities can prevent and mitigate development of mental disorders, including depression, anxiety, sleep disturbances and cognitive alterations [1, 7, 8, 12-14, 20, 21-24]. According torecent myco-pharmacological research, Agaricomycetes mushrooms are producers of different neuroprotective compounds [8, 20, 25-27].

The current paper is directed to the evaluation of resource value of Agaricomycetes medicinal mushrooms growing in Armenia with potential neuroprotective activity (NPA) and discusses future perspectives of their usage in biomedicine.

Neuroprotective Compounds of Agaricomycetes Mushrooms. Mushrooms are widely distributed worldwide and have been appreciated in traditional medicine for their nutritional and medicinal properties [6, 7]. Edible and inedible mushrooms are industrially cultivated organisms however their biotechnological potential and perspectives of usage in biomedicine have not been fully exploited [15].

The polysaccharides ( $\beta$-glucans) are considered one of the major bioactive compounds in mushrooms [6, 7]. The polysaccharides isolated from medicinal mushrooms Agaricus bisporus, Cantharellus cibarius, Coprinellus truncorum, Coprinus comatusand Inonotus obliquus (Chaga mushroom), distributed also in Armenia showed significant antioxidant, anti-inflammatory, anti-cholinesterase (AChE) and neuroprotective activities which may allow suggest them in the palliative treatment of NDD [11, 28-31].

Mushroom-derived terpenoids, steroids, sterols and phenolics are also known by their diverse pharmacological effects, including anti-inflammatory, antioxidant and neuroprotective [1, 3-5, 32, 33]. The NPA of Hericium erinaceus (Lion's mane) has been attributed to cyathane diterpenoids as erinacinesthat can stimulate the production of brain-derived neurotrophic factor [34]. New lanostane triterpenes and aromatic meroterpenoids with antioxidant and neuroprotective activities were isolated from fruiting bodies of Ganoderma lucidum (Reishi ou Ling Zhi) [5]. Study of total phenolic content, as well as antioxidant, AChE, tyrosinase, $\alpha$-amylase and $\alpha$-glucosidase activities of polypore mushrooms as Ganoderma applanatum, Trametes gibbosa and Trametes versicolor suggest that they may be considered as a source of neuroprotective food supplements [3, 5, 32].

\section{Changes may still occur before final publication.}


Agaricomycetous Mushrooms as a Source for Neuroprotective Biotech Products. The cultivated edible mushroom, $H$. erinaceus is an important medicinal fungus with immunomodulatory, anti-mutagenic, antioxidant, anti-inflammatory and antitumor properties. Myco-pharmacological studies have attracted considerable attention on $H$. erinaceus as a neuroprotector to prevent NDD, including dementia, anxiety or depression [7, 13, 20, 25, 35-38].

Scientific dada have reported antioxidant and neuroprotective activities of Ganoderma mushrooms [5, 9, 22, 39]. The ganoderic acid and lucidone A isolated from G. lucidum delay $\mathrm{AD}$ progression [22]. The inhibition of cholinesterase, tyrosinase, $\alpha$-amylase and $\alpha$-glucosidase enzyme activities, as well as antioxidant effect of extracts from medicinal mushrooms of G. applanatum and Ganoderma resinaceum allows suggesting them as a source to prepare new food supplements and develop new drug formulations with NPA [3].

Oyster mushrooms (Pleurotus spp.) possess a high quantity of antioxidants, including ergothioneine, adenosine, and polyphenol derivatives which reduce oxidative stress-related aging. Consumption of edible medicinal mushroom Pleurotus eryngii (King Oyster Mushroom) delayed the development of brain atrophy, ameliorated memory deficit in mice and significantly decreased the levels of brain phosphorylated $\tau$-protein, A $\beta$ plaque deposition and malondialdehyde [26]. The AChE activity was detected in Pleurotus ostreatus (Oyster Mushroom), however the effect was weaker than the effect of galantamine [10].

Several white rot polypore Trametes (= Coriolus) species, such as Trametes gibbosa, T. hirsute, T. pubescens and T. versicolor have been used for centuries in traditional medicine [7]. In vitro antioxidant, anti-diabetes, anti-dementia and antiinflammatory activities of Trametes species were evaluated. The importance of nutra- and nutriceuticals derived from these polypore mushrooms as neuroprotectores have been considered [19, 32].

The antioxidant power and NPA of edible mushroom Amanita caesarea (Caesar's mushroom) have been reported to alleviate the deposition of amyloid beta $(\mathrm{A} \beta)$ protein in the brain and improve the central cholinergic system function. A. caesarea as a potential food for treatment or prevention of NDD was reported [23]. Muscimol is the main compound found in toxic Amanita muscaria (Fly agaric or Fly amanita) with a suppressive effect on essential tremor, without impairing speech and coordination in Parkinson-affected patients. The extract of A. muscaria showed significant NPA on in vitro neurotoxicity models [40].

Mushrooms with Neuroprotective Potential Distributed in Armenia. The forest regions in Armenia rich with mushroom biodiversity are mainly distributed in North-Eastern (Ijevan and Lori floristic regions) and South-Eastern (Zangezur floristic region) parts of the country [41, 42].

Seventeen edible and inedible agaricoid, polyporoid, hymenochaetoid and cantharelloid Agaricomycetes medicinal species with potential NPA belonging to ecological groups of saprotrophes and xylotrophes have been recorded in Armenia. The antioxidative, anti-inflammatory and neuroprotective effects of these species have been reported (see Table) [1, 3, 5, 8-11, 17, 19, 27, 36, 37, 43, 44].

\section{Changes may still occur before final publication.}


The Agaricomycetes mushrooms with potential neuroprotective activity growing in Armenia

\begin{tabular}{|c|c|c|c|c|c|c|}
\hline & Species & Order & Edibility & $\begin{array}{l}\text { Ecological } \\
\text { group }\end{array}$ & $\begin{array}{c}\text { Bioactive compound, } \\
\text { medicinal activity }\end{array}$ & References \\
\hline 1. & $\begin{array}{l}\text { Agaricus bisporus } \\
\text { (J.E. Lange) Imbach }\end{array}$ & Agaricales & edible & $\begin{array}{c}\text { Soil } \\
\text { saprotrophe }\end{array}$ & $\begin{array}{c}\text { Polysaccharide, } \\
\text { against Alzheimer's } \\
\text { disease }\end{array}$ & [28] \\
\hline 2. & $\begin{array}{l}\text { Amanita muscaria } \\
\text { (L.) Lam. }\end{array}$ & Agaricales & $\begin{array}{c}\text { inedible, } \\
\text { toxic }\end{array}$ & \begin{tabular}{|c|} 
Soil \\
saprotrophe \\
\end{tabular} & Muscimol, neuroprotective & {$[40]$} \\
\hline 3. & $\begin{array}{l}\text { Cantharellus cibarius } \\
\text { Fr. }\end{array}$ & Cantharellales & edible & \begin{tabular}{|c|} 
Soil \\
saprotrophe \\
\end{tabular} & Polysaccharide, neuroprotective & {$[11]$} \\
\hline 4. & $\begin{array}{l}\text { Coprinellus truncorum } \\
\text { (Scop.) Redhead, } \\
\text { Vilgalys \& Moncalvo }\end{array}$ & Psathyrellales & inedible & \begin{tabular}{|c|} 
Soil \\
saprotrophe/ \\
xylotroph \\
\end{tabular} & $\begin{array}{c}\text { Polysaccharide, antioxidant, anti- } \\
\text { cholinesterase }\end{array}$ & {$[17,31]$} \\
\hline 5. & $\begin{array}{l}\text { Coprinus comatus } \\
\text { (O.F. Müll.) Pers. }\end{array}$ & Agaricales & edible & \begin{tabular}{|c|} 
Soil \\
saprotrophe/ \\
xylotroph \\
\end{tabular} & $\begin{array}{c}\text { Polysaccharide, antioxidant, anti- } \\
\text { cholinesterase }\end{array}$ & {$[17,31]$} \\
\hline 6. & $\begin{array}{l}\text { Flammulina velutipes } \\
\text { (Curtis) Singer }\end{array}$ & Agaricales & edible & Xylotrophe & $\begin{array}{c}\text { Polysaccharides, } \\
\text { neuroprotective, } \\
\text { mitigate neurodegeneration }\end{array}$ & {$[8,20]$} \\
\hline 7. & \begin{tabular}{|c|} 
Ganoderma applana- \\
tum (Pers.) Pat. \\
[=Ganoderma lipsiense \\
(Batsch) G.F.] \\
\end{tabular} & Polyporales & inedible & Xylotrophe & $\begin{array}{c}\text { Triterpenes, aromatic } \\
\text { meroterpenoids, neuroprotective, } \\
\text { against Alzheimer's disease }\end{array}$ & {$[5]$} \\
\hline 8. & $\begin{array}{l}\text { Ganoderma lucidum } \\
\text { (Curtis) P.Karst. }\end{array}$ & Polyporales & inedible & Xylotrophe & $\begin{array}{c}\text { Triterpenes, aromatic } \\
\text { meroterpenoids, antioxidant, anti- } \\
\text { cholinesterase, neuroprotective, } \\
\text { against Alzheimer's disease } \\
\end{array}$ & $\begin{array}{l}{[3,5,9} \\
22,39]\end{array}$ \\
\hline 9. & $\begin{array}{l}\text { Hericium erinaceus } \\
\text { (Bull.: Fr.) Pers. }\end{array}$ & Russulales & edible & Xylotrophe & \begin{tabular}{|c|} 
Polysaccharides, cyathane \\
diterpenoids, hericenones, \\
erinacines, antioxidant, anti- \\
depressant, memory enhancer, \\
neuro-stimulating, \\
\end{tabular} & $\begin{array}{l}{[4,13,21} \\
25,30 \\
34-38]\end{array}$ \\
\hline 10. & $\begin{array}{l}\text { Inonotus obliquus } \\
\text { (Ach. ex Pers.) }\end{array}$ & $\begin{array}{l}\text { Hymeno- } \\
\text { chaetales }\end{array}$ & inedible & Xylotrophe & $\begin{array}{c}\text { Polysaccharides, proliferate } \\
\text { human neurogliocytoma cells }\end{array}$ & [29] \\
\hline 11. & $\begin{array}{l}\text { Laetiporus sulphureus } \\
\text { (Bull.) Murrill }\end{array}$ & Polyporales & edible & Xylotrophe & $\begin{array}{c}\text { Polysaccharides, antioxidant, } \\
\text { against Alzheimer and Parkinson } \\
\text { diseases }\end{array}$ & {$[10]$} \\
\hline 12. & $\begin{array}{c}\text { Phellinus pini } \\
\text { (Brot.) A. Ames } \\
\text { [=Porodaedalea pini } \\
\text { (Brot.) Murrill] }\end{array}$ & $\begin{array}{l}\text { Hymeno- } \\
\text { chaetales }\end{array}$ & inedible & Xylotrophe & $\begin{array}{c}\text { Polysaccharides, phenolic } \\
\text { compound hispidin, phenolic } \\
\text { acids, polysaccharides, anti- } \\
\text { cholinesterase, anti-inflammatory }\end{array}$ & {$[43]$} \\
\hline 13. & $\begin{array}{l}\text { Pleurotus eryngii } \\
\text { (DC.) Quél. }\end{array}$ & Agaricales & edible & Xylotrophe & \begin{tabular}{|c|} 
Polysaccharides, phenolic \\
compounds, ameliorate memory \\
and learning deficit, against \\
Alzheimer's disease \\
\end{tabular} & {$[14,26]$} \\
\hline 14. & $\begin{array}{l}\text { Pleurotus ostreatus } \\
\text { (Jacq.) P. Kumm. }\end{array}$ & Agaricales & edible & Xylotrophe & $\begin{array}{c}\text { Polysaccharides, antioxidant, } \\
\text { against Alzheimer and Parkinson } \\
\text { diseases }\end{array}$ & {$[10]$} \\
\hline 15. & $\begin{array}{l}\text { Trametes gibbosa } \\
\text { (Pers.) Fr. }\end{array}$ & Polyporales & inedible & Xylotrophe & $\begin{array}{l}\text { Polysaccharides, phenolics, anti- } \\
\text { oxidative, anti-neurodegenerative }\end{array}$ & [27] \\
\hline 16. & $\begin{array}{l}\text { Trametes pubescens } \\
\text { (Schumach.) Pilát }\end{array}$ & Polyporales & inedible & Xylotrophe & $\begin{array}{l}\text { Polysaccharides, phenolics, } \\
\text { antioxidative, anti- } \\
\text { neurodegenerative }\end{array}$ & {$[27,44]$} \\
\hline 17. & $\begin{array}{l}\text { Trametes versicolor } \\
\text { (L.) Lloyd }\end{array}$ & Polyporales & inedible & Xylotrophe & $\begin{array}{l}\text { Polysaccharides, phenolics, } \\
\text { antioxidant, anti-dementia, anti- } \\
\text { inflammatory }\end{array}$ & {$[27,32]$} \\
\hline
\end{tabular}

\section{Changes may still occur before final publication.}


Conclusion. Given the aging of the population, finding natural resources with a potential effect to prevent or support the treatment of neurodegenerative diseases is a crucial societal issue. Indeed, further evaluation of resource value and biotechnological potential of Armenian medicinal Agaricomycetes mushrooms will assist to use them as potential natural source to formulate novelpotential neuroprotective myco-pharmaceuticals and functional foods without adverse side effects for preventingor mitigating different diseases, including neurodegenerative.

The authors are thankful to Dr. A. Barkhudaryan for a critical review of the manuscript.

This work was supported by the Science Committee of the MESCS RA, in the frames of the research thematic project No. 18T-1F115.

Received 17.07.2020

Reviewed 15.08.2020

Accepted 00.00.2020

\section{REFERENCES}

1. Palacios I., Lozano M., Moro C., et al. Antioxidant Properties of Phenolic Compounds Occurring in Edible Mushrooms. Food. Chem. 28 (2011), 674-678.

2. De Silva D.D., Rapior S., Sudarman E., et al. Bioactive Metabolites from Macrofungi: Ethnopharmacology, Biological Activities, Chemistry. Fungal Divers. 62 (2013), 1-40.

3. Zengin G., Sarikurkcu C., Gunes E., et al. Two GanodermaSpecies: Profiling of Phenolic Compounds by HPLC-DAD, Antioxidant, Antimicrobial and Inhibitory Activities on Key Enzymes Linked to Diabetes Mellitus, Alzheimer's Disease and Skin Disorders. Food Funct. 6 : 8 (2015), 2794-2802.

4. Wang X.Y., Zhang D.D., Yin J.Y., et al. Recent Developments in Hericium erinaceus Polysaccharides: Extraction, Purification, Structural Characteristics and Biological Activities. Crit. Rev. Food Sci. Nutr. 59 : 1 (2019), S96-S115.

5. Wang C., Liu X., Lian C., et al. Triterpenes and Aromatic Meroterpenoids with Antioxidant Activity and Neuroprotective Effects from Ganoderma lucidum. Molecules 24 : 23 (2019), 4353.

6. Badalyan S.M., Zambonelli A. Biotechnological exploitation of macrofungi for the production of food, pharmaceuticals and cosmeceuticals. In: Sridhar K.R., Deshmukh S.K. (eds) Advances in Macrofungi: Diversity, Ecology and Biotechnology. CRC Press, Boca Raton (2019), 199230.

7. Badalyan S.M., Barkhudaryan A., Rapior S. Recent progress in research on the pharmacological potential of mushrooms and prospects for their clinical application. In: Agrawal D.C., Dhanasekaran M. (eds) Medicinal Mushrooms: Recent Progress in Research and Development. Springer Nature, Singapore (2019), 1-70.

8. Sabaratnam V., Phan C.W. Neuroactive components of culinary and medicinal mushrooms with potential to mitigate age-related neurodegenerative diseases. In: Brahmachari G (ed) Discovery and development of neuroprotective agents from natural products. Elsevier (2017), 401-413.

9. Ćilerdžić J.L., Sofrenić I.V., Tešević V.V., et al. Neuroprotective Potential and Chemical Profile of Alternatively Cultivated Ganoderma lucidumBasidiocarps. Chem. Biodivers. $15: 5$ (2018), e1800036.

10. Ć́ilerdžić J., Galić M., Vukojević J.,Stajic M. Pleurotus ostreatus and Laetiporus sulphureus (Agaricomycetes): Possible Agents against Alzheimer and Parkinson Diseases. Int. J. Med. Mushrooms $21: 3$ (2019), 275-289.

\section{Changes may still occur before final publication.}


11. Lemieszek M.K., Nunes F.M., Cardoso C., et al. Neuroprotective Properties of Cantharellus cibarius Polysaccharide Fractions in Different in vitro Models of Neurodegeneration. Carbohydr. Polymers 197 (2018), 598-607.

12. Bell V., Ferrão J., Chaquisse E., et al. Role of Mushrooms in Autism. Austin J. Nutri. Food Sci. $7: 6$ (2019), 1128

13. Chong P.S., Fung M.L., Wong K.H., Lim L.W. Therapeutic Potential of Hericium erinaceus for Depressive Disorder. Int. J. Mol. Sci. 21 : 1 (2019), E163.

14. Liang C.-H., Huang P.-C., Mau J.-L., Chiang S.-S. Effect of the King Oyster CulinaryMedicinal Mushroom Pleurotus eryngii (Agaricomycetes) Basidiocarps Powder to Ameliorate Memory and Learning Deficit in Ability in A $\beta$-Induced Alzheimer's Disease C57BL/6J Mice Model. Int. J. Med. Mushrooms 22 : 2 (2020), 145-159.

15. Kües U., Badalyan S.M. Making Use of Genomic Information to Explore the Biotechnological Potential of Medicinal Mushrooms. In: Agrawal D.C., et al. (eds) Medicinal Plants and Fungi: Recent Advances in Research and Development, Medicinal and Aromatic Plants of the World, vol 4. Springer, New York (2017), 397-458.

16. Badalyan S.M., Gharibyan N.G. Characteristics of Mycelial Structures of Different Fungal Collections. YSU Press, Yerevan, 2017.

17. Badalyan S.M. Medicinal Coprinoid Mushrooms (Agaricomycetes) Distributed in Armenia (Review). Int. J. Med. Mushrooms 22 : 3 (2020), 257-267.

18. Uddin M.S., Ashraf G.M. Introductory Chapter: Alzheimer's Disease - The Most Common Cause of Dementia. In: Ashraf G.M., Uddin M.S. (eds) Advances in Dementia Research, IntechOpen, 2018.

19. Trovato Salinaro A., Pennisi M., Di Paola R., et al. Neuroinflammation and Neurohormesis in the Pathogenesis of Alzheimer's Disease and Alzheimer-Linked Pathologies: Modulation by Nutritional Mushrooms. Immun. Ageing 15 (2018), 8.

20. Phan C.W., David P., Sabaratnam V. Edible and Medicinal Mushrooms: Emerging Brain Food for the Mitigation of Neurodegenerative Diseases. J. Med. Food 20 : 1 (2017), 1-10.

21. Rossi P., Cesaroni V., Brandalise F., et al. Dietary Supplementation of Lion's Mane Medicinal Mushroom, Hericium erinaceus (Agaricomycetes), and Spatial Memory in Wild-Type Mice. Int. J. Med. Mushroom 20 : 5 (2018), 485-494.

22. Lai G., Guo Y., Chen D., et al. Alcohol Extracts from Ganoderma lucidum Delay the Progress of Alzheimer's Disease by Regulating DNA Methylation in Rodents. Front. Pharmacol. 10 (2019), 272.

23. Li Z., Chen X., Lu W., et al. Wang D. Anti-Oxidative Stress Activity is Essential for Amanita caesareaMediated Neuroprotection on Glutamate-Induced Apoptotic HT22 Cells and an Alzheimer's Disease Mouse Model. Int. J. Mol. Sci. 18 : 8 (2017), E1623.

24. Ho L.H., Zulkifli N.A., Tan T.C. Edible mushroom: Nutritional properties, potential nutraceutical values, and its utilisation in food product development. In: An introduction to mushroom (2020), IntechOpen.

25. Cheng J.H., Tsai C.L., Lien Y.Y., et al. High Molecular Weight of Polysaccharides from Hericium erinaceus against Amyloid beta-Induced Neurotoxicity. BMC Complement Altern. Med. 16 (2016), 170.

26. Zhang C.J., Guo J.Y., Cheng H., et al. Protective Effects of the King Oyster Culinary-Medicinal Mushroom, Pleurotus eryngii (Agaricomycetes), Polysaccharides on $\beta$-Amyloid-Induced Neurotoxicity in PC12 Cells and Aging Rats, In Vitro and In Vivo Studies. Int. J. Med. Mushrooms $22: 4$ (2020), 325-333.

27. Knežević A., Stajić M., Sofrenić I., et al. Antioxidative, Antifungal, Cytotoxic and AntiNeurodegenerative Activity of Selected Trametes Species from Serbia. PLoS One 13 : 8 (2018), e0203064.

28. Mahmoud M.G., Ibrahim A.Y., et al. Therapeutic Potential and Structural Elucidation of a Water-Soluble Polysaccharide of a Wild Edible Mushroom Agaricus bisporus against Neurodegenerative Disease, Alzheimer. World J. Pharm. Sci. 2 : 10 (2014), 1136-1145.

29. Ning X., Luo Q., Li C., et al. Inhibitory Effects of a Polysaccharide Extract from the Chaga Medicinal Mushroom, Inonotus obliquus (Higher Basidiomycetes), on the Proliferation of Human Neurogliocytoma Cells. Int. J. Med. Mushrooms 16 : 1 (2014), 29-36.

\section{Changes may still occur before final publication.}


30. He X., Wang X., Fang J., et al. Structures, Biological Activities, and Industrial Applications of the Polysaccharides from Hericium erinaceus (Lion’s Mane) Mushroom: A Review. Int. J. Biol. Macromol. 97 (2017), 228-237.

31. Pejin B., Tešanović K., Jakovljević D., et al. The Polysaccharide Extracts from the Fungi Coprinus comatus and Coprinellus truncorum Do Exhibit AChE Inhibitory Activity. Nat. Prod. Res. 33 : 5 (2018), 750-754.

32. Pop R.M., Puia I.C., Puia A., et al. Characterization of Trametes versicolor: Medicinal Mushroom with Important Health Benefits. Not. Bot. Horti. Agrobo. 46 : 2 (2018), 343-349.

33. Dhakal S., Kushairi N., Phan C.W., et al. Dietary Polyphenols: AMultifactorial Strategy to Target Alzheimer's Disease. Int. J. Mol Sci. 20 : 20 (2019), E5090.

34. Rupcic Z., Rascher M., Kanaki S., et al. Two New Cyathane Diterpenoids from Mycelial Cultures of the Medicinal Mushroom Hericium erinaceus and the Rare Species, Hericium flagellum. Int. J. Mol. Sci. 19 : 3 (2018), E740.

35. Phan C.W., Lee G.S., Hong S.L., et al. Hericium erinaceus (Bull.: Fr.) Pers. cultivated under tropical conditions: isolation of hericenones and demonstration of NGF-mediated neurite outgrowth in PC12 cells via MEK/ERK and PI3K-Akt signaling pathways. Food Funct. 5 : 12 (2014), 160-169.

36. Kushairi N., Phan C.W., Sabaratnam V., et al. Lion's Mane Mushroom, Hericium erinaceus (Bull.: Fr.) Pers. Suppresses H2O2-Induced Oxidative Damage and LPS-Induced Inflammation in HT22 Hippocampal Neurons and BV2 Microglia. Antioxidants 8 : 8 (2019), 261.

37. Saitsu Y., Nishide A., Kikushima K., et al. Improvement of cognitive functions by oral intake of Hericium erinaceus. Biomed. Res. 40 : 4 (2019), 125-131.

38. Limanaqi F., Biagioni F., Busceti C.L., et al. Potential Antidepressant effects of Scutellaria baicalensis, Hericium erinaceus and Rhodiola rosea. Antioxidants 9 : 3 (2020), 234.

39. Zhao C., Zhang C., Xing Z., et al. Pharmacological Effects of Natural Ganoderma and its Extracts on Neurological Diseases: A Comprehensive Review. Int. J. Biol. Macromol. 121 (2019), 1160-1178.

40. Kondeva-Burdina M., Voynova M., Shkondrov A., et al. Effects of Amanita muscariaExtract on Different In VitroNeurotoxicity Models at Sub-Cellular and Cellular Levels. Food Chem. Toxicol. 132 (2019), 110687.

41. Badalyan S.M., Gharibyan N.G. Macroscopic Fungi from Central Part of Virahayotz Mountains' Forests of Armenia and Their Medicinal Properties. YSU Press, Yerevan (2008)

42. Badalyan S.M., Gharibyan N.G. Diversity of Polypore Bracket Mushrooms, Polyporales (Agaricomycetes) Recorded in Armenia and their Medicinal Properties. Int. J. Med. Mushrooms 18 : 4 (2016), 347-354.

43. Im K.H., Nguyen T.K., Kim J.K., et al. Evaluation of Anticholinesterase and Inflammation Inhibitory Activity of Medicinal Mushroom Phellinus pini (Basidiomycetes) Fruiting Bodies. Int. J. Med. Mushrooms 17 : 2 (2015), 1011-1022.

44. Im K.H., Nguyen T.K., Choi J., Lee T.S. In Vitro Antioxidant, Anti-Diabetes, Anti-Dementia, and Inflammation Inhibitory Effect of Trametes pubescens Fruiting Body Extracts. Molecules 21 : 5 (2016), E639.

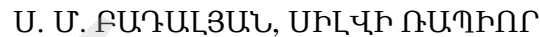

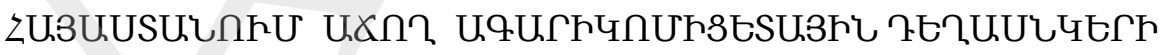

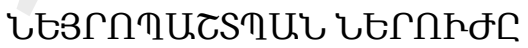

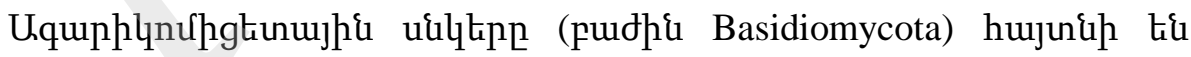

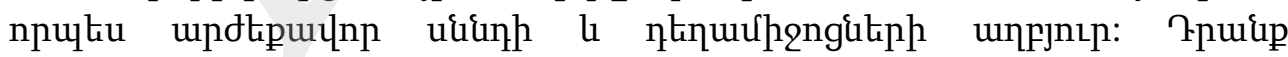

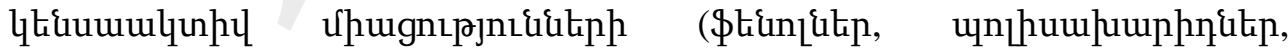

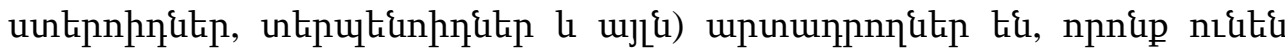

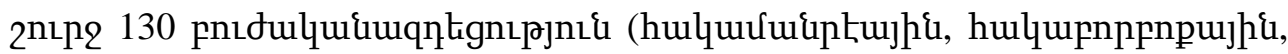

\section{Changes may still occur before final publication.}




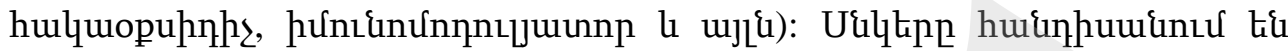

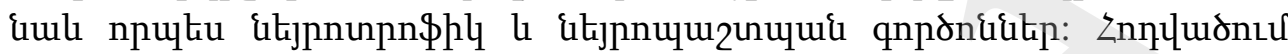

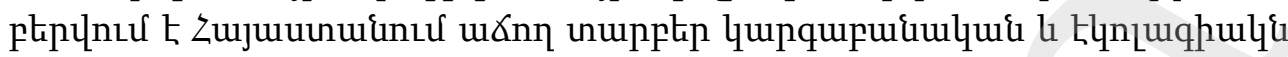

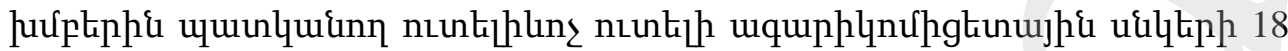

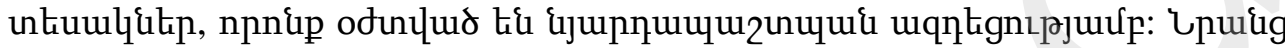

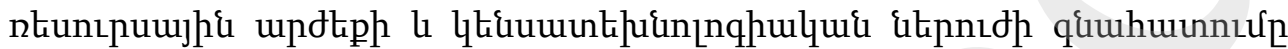

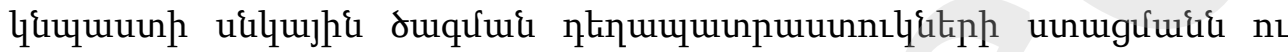

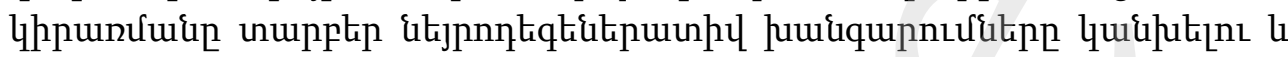
utinutint ququunulyn!:

\section{С. М. БАДАЛЯН, С. РАПИОР}

\section{АГАРИКОМИЦЕТНЫЕ ЛЕКАРСТВЕННЫЕ ГРИБЫ С НЕЙРОРПОТЕКНЫМ ПОТЕНЦИАЛОМ РАСТУЩИХ В АРМЕНИИ}

Грибы Agaricomycetes (отдел Basidiomycota) являются источниками ценных пищевых и лекарственных продуктов. Они являются производителями биоактивных соединений (фенолов, полисахаридов, стероидов, терпеноидов и т.д.), обладающих около 130 терапевтическими эффектами (противомикробным, противовоспалительным, антиоксидантным, иммуномодулирующим и др.). Грибы также известны как потенциальные нейротрофические и нейропротекторные агенты. Было обнаружено, что восемнадцать видов съедобных и несъедобных агарикомицетных грибов, растущих в Армении, обладают нейропротекторной активностью. Оценка их ресурсной ценности и биотехнологического потенциала поможет разработке новых микопрепаратов для предотвращения и смягчения симптомов различных нейродегенеративных нарушений.

\section{Changes may still occur before final publication.}

